\author{
Professor Cristian PĂUN, PhD \\ E-mail: cristian.paun@ rei.ase.ro \\ Associate Professor Vladimir TOPAN, PhD \\ E-mail: topan_vlad@yahoo.com \\ Professor Costea MUNTEANU, PhD \\ E-mail: costea_munteanu@yahoo.com \\ Associate Professor Radu NECHITA, PhD \\ E-mail: radunechita@gmail.com
}

\title{
INTEREST RATE GAP DETERMINANTS: A GLOBAL PERSPECTIVE
}

\begin{abstract}
This article is focused on an important financial issue - the gap between the interest rate required for granted loans (ask interest rate) and interest rate paid for demand and term deposits (bid interest rate) in the banking sector. This interest rate gap represents the profit associated to commercial banking sector and it is, according to economic theory, sensitive to various factors. This paper discusses the theoretical background of the interest rate gap and a few related concepts: time preference, interest rates, capital, banking profits, etc. The research hypotheses are derived from the theoretical background and are empirically tested by using panel data analysis methodology (fixed and random effects). The paper provides a perspective from global financial markets by using a panel of 78 countries with data covering the period between 1999 and 2014. The conclusions of the research confirm the hypothesis that the interest rate gap is influenced by monetary expansion and by financial development and sophistication of countries included in the study. The empirical test results do not confirm the influence of government or state activity in general on such gap.

Keywords: global capital markets, interest rate, capital, monetary policy, financial sophistication.
\end{abstract}

\section{JEL Classification: F42, F34, B22, C23}

\section{Introduction}

Capital and interest rate are the most complex and fundamental concepts of economic theory. Capital accumulation by savings is considered to be one of the most important factor for economic growth and development by the major schools of economic thoughts. Financial markets and institutions are strongly supported by central banks that give to them the privilege to operate with fractional reserves in case of demand deposits. The low cost liquidity provided nowadays to these financial institutions by central banks strongly affects the gap between bid interest rate (paid by the banks for attracted deposits) and ask interest rate (required by the

DOI: 10.24818/18423264/53.1.19.13 
Cristian Păun, Vladimir Topan, Costea Munteanu, Radu Nechita

banks for loans granted to different economic agents). This paper is focused on the theory of capital and interest rate in order to understand the nature and the role of interest rate gap for financial sector. We investigated the interest rate gap's determinants by using balanced panel data research framework including 78 countries and relevant proxy variables covering a period of 16 years $(1999-2014)$. The conclusions we found are robust and consistent with economic theory, confirming a strong relationship of interest rate gap and financial issues.

\section{Literature review}

\subsection{Introductory remarks}

The problem of interest - along with that of capital, with which it is almost always intertwined - is among the most difficult in economics. Marred throughout the ages by the moral and religious indictment against usury, the problem received its first satisfactory theoretical exposition at the hands of von Böhm-Bawerk and Menger. In his magnum opus, Capital and Interest (3 vols.) Böhm-Bawerk presented clearly for the first time the problem of interest as a value spread (Hülsmann, 2002, p. 78), namely between the value of present and future goods (Böhm-Bawerk, 1959 [1884, 1889, 1921], vol. II, pp. 259ff). Specifically, he reached the conclusion that the most potent explanation of the origin and nature of interest resides in the discount that future goods make as compared to presents goods of the same quality and quantity, a phenomenon he called time-preference. Thus he adequately integrated the time element into the theoretical discussion in economics and with one stroke managed to explain three apparently dissimilar phenomena: the interest paid on productive loans, the "surplus value" ("originary" interest, in his terminology) gained by the capitalist entrepreneurs and the interest paid on consumer loans. After Böhm-Bawerk's pioneering work a few strands on interest rate theory emerged, some more eclectic, some more purist. The purist line - the so-called "pure time-preference theory of interest (PTPTI)" which we will deal with below - was followed by authors such as Frank A. Fetter (1863-1949) (Fetter, 1977), Ludwig von Mises (1881-1973) (Mises, 2008[1949]) and Murray N. Rothbard (1926-1995) (Rothbard, 2009 [1962]). Among the famous followers of the more eclectic line could be counted: John Bates Clark (1847-1938) (Clark, 1908[1899]), Frank H. Knight (1885-1972) (Knight, 1933, 1934), Irving Fisher (1867-1947) (Fisher, 1930), F.A. Hayek (1899-1992) (Hayek, 2008), John Maynard Keynes (1883-1946) (Keynes, 2007), Knut Wicksell (1851-1926) (Wicksell, 1962[1936]), all the way up to the modern scholars of the financial field, with figures such as Frederic S. Mishkin (n. 1951) (Mishkin, 2004) for whom the fundamentals behind interest do not even seem to matter anymore (Mera, 2010). For these latter authors, interest springs form a multitude of causes, among which one could count: time-preference, productivity, liquidity preference and yield to maturity etc. (Hazlitt, 2007 [1959], pp. 197ff). 
Interest Rate Gap Determinants: A Global Perspective

\subsection{The Pure Time Preference Theory of Interest (PTPTI) and the nature of capital}

Capital as a concept comes from two main lines of thought: the idea of capital goods as "produced means of production"; and the more abstract concept of "capital" that springs from the theory of economic calculation. To explain the idea of "produced means of production" one has to start from the classical distinction in economics between consumption goods and means of production. Namely, consumption goods are those that directly satisfy needs without the necessary cooperation of other goods, while means or factors of production are those that only indirectly satisfy needs and only with the cooperation of other such goods (Menger, 2007, p. 56; Mises, 2008, p. 93; Rothbard, 2009, p. 8). Among the factors of production, another important distinction that is also a locus clasicus is that between originary (those directly available for production, either provided by the external environment or nature, or inherent in the human person such as labour) factors of production and produced factors of production. The produced factors of production also acquired - more or less felicitously - the designation of capital goods. Thus, directly associated with the idea of capitalist entrepreneurship became the ownership of such produced instruments of production, and often, the income of the seemingly passive owner of such assets (which could be grouped and combined with originary factors of production into factories) was considered to be the "interest" of "the capitalist". As Carl Menger and Böhm-Bawerk already observed, in its essence, the possession (or availability through hire) of capital goods renders the fundamental service of bringing the owner/user closer to his productive goal. Thus, if a certain tool doubles the production of widgets, but the production of the tool would require one month, the entrepreneur who already has the tool is one month closer, other things equal, to the double figure in widget production then the entrepreneur without the tool. Thus, as synthesized by Rothbard (Rothbard, 2009, p. 58) capital goods are stored up land, labour and time. And in a fundamental sense, capital goods beget no net income other than the payment for waiting. Strangely enough, an economy which wants to get closer to higher levels of productivity, must previously elongate its structure of production. This is the process usually called capital accumulation. Finally, an economy with a large stock of capital (especially per capita) would usually be called "developed" (Menger, 2007, p.74). The second stream of thought on the capital concept is connected with the problem of economic calculation. The concept - economic calculation - was made famous in the socialist calculation debate of the twenties and thirties of the twentieth century in which such luminaries as Ludwig von Mises (Mises, 1920; Mises, 2008, pp. 201ff and pp. 685ff) and Friedrich August von Hayek debated Oskar Lange, Frederick Taylor and others on the possibility of socialism (Hayek, 1935). The main idea at stake, best captured by the work of Ludwig von Mises, is that a complex structure of production as that of modern 
Cristian Păun, Vladimir Topan, Costea Munteanu, Radu Nechita

economies, with thousands and thousands of stages of production and intermediary goods cannot be rationally coordinated unless there are market prices for those factors of production, these being dependent in their turn on the existence of markets for such factors of production, which leads to the necessity of the existence of private property over factors of production - the very opposite of the main practical or operational tenet of all socialist programs, namely the abolition of private property. Capital in this sense is an abstract monetary value, even though we should immediately observe that it is never entirely disconnected from the actual existence of real, tangible capital goods in the above sense.

\subsection{The Interest rate gap in light of the pure-time preference theory of interest}

Above we have sketched a few fundamentals of PTPTI. In what follows we will try to connect it with the problem of the interest rate gap, further preparing the way for the empirical part of the paper. We will do this in two steps: first, we will sketch some fundamental reasons for the existence of an interest rate gap; and then we will try to outline a few hypotheses concerning the falsification, or artificial modification of this gap, namely as a consequence of certain institutional factors or interventions in what we have above called the time-market (in the full PTPTI sense as exposed e.g. in Rothbard, 2009, pp. 375ff and pp. 390ff).

\subsubsection{The interest rate gap, naturally}

In light of PTPTI, the interest rate gap in the ERE is zero (Rothbard, 2009, p. 372 , p. 386). We are using the ERE - evenly rotating economy - type of equilibrium construct as it was the background for the most important PTPTI theorists. By means of this imaginary construct, Ludwig von Mises tried to make only a limited use of equilibrium, namely for the explanation of the difference between interest and pure economic profit. Thus, he tried to think through a situation where no pure economic profits would be gained by the entrepreneurs. For him the main feature of such a final point is the absence of (relevant) change, which triggers with it the absence of uncertainty. Thus, entrepreneurs could only gain "normal" income, namely that of the capitalist, or interest, which is obviously in this setting - a reward for waiting. Or, to use the terminology introduced above, the interest gain form the exchange of present goods (advances in production) for future goods (receipts from sale of produced goods). Because in such a setting no future surprises are expected by entrepreneurs and all agents, no intermediation could actually take place, as all possible partners would know one of the other, so they would just "cut the middleman", as they say. Thus, in the setting of ERE, a difference - or a gap - between paid interest and received interest could not emerge. Moving away from the unrealistic setting of the ERE, we can easily account for the existence of an interest rate gap due to the presence of uncertainty. And we could include here both types of uncertainty discussed above: 
Interest Rate Gap Determinants: A Global Perspective

probabilistic uncertainty and genuine uncertainty (Mises, 2008, ch. VI, pp. 105118). Probabilistic uncertainty could be simply factored into interest rates as a consequences of the amassing of statistical record of certain debtors or group/category of debtors and the rates of their default. An intermediary with good credit record could thus arbitrage between possible creditors and debtors with credit standing poorer than their own. In a sense, in this scenario the credit intermediary and the beneficiary of the interest rate gap would function as an insurer (implied by de Soto, 2006, p. 289). In the case of genuine uncertainty, an intermediary ventures to borrow and lend just based on some equity of his own and the hoped for success of his entrepreneurial foresight. Being more alert or better at judging the future constellation of market data, he anticipates changes in the interest rates. And this allows him to arbitrage inter-temporally. Accordingly, the interest rate gap in its fundamentals invites two conclusions: first, if it can be accounted by probabilistic uncertainty (risk) it must be a rather slowly changing phenomenon (only a "nominal" gap), having a certain fixity and resilience. Second, if accounted for by the pure entrepreneurial (genuine uncertainty) element, it can only be ephemeral, as it implies that some entrepreneurs see better and sooner than others - and this in turns invites arbitrage. A less developed financial sector means less competition, and will permit less entrepreneurial competition and arbitrage, thus corroborating with higher interest rate gaps. On the contrary, a well-developed and fully functional financial sector will bring about increased competition and options for the placement of savings, thus eroding the interest rate gap as discussed in this paper.

\subsubsection{The interest rate gap, artificially}

Thus far we have established reasons for the existence of a natural, timemarket driven, interest rate gap. In what follows we will move on to discuss a few of the sources of artificial augmentation of this gap. Namely, we will first investigate the role of a specific element in the present financial setting - that is monetary policy. And, second, we will try to generalize the analysis by trying to see whether any connection could be thought of between government interventions in general, in all its aspects and dimensions, and the interest rate gap. We expect the first factor to be much more relevant than the second. As we have said above, the possibility of a unified time-market has a conditio sine qua non in the use of a general medium of exchange, or a money (Herbener, 2011, p. 15). In a sense, this is only an implication (insufficiently studied, in our opinion) of the economic calculation debate evoked earlier in this material. One of the great (infelicitous) fictions of economics is the so-called "barter fiction", namely the idea that a complex economy can be safely described in terms of barter exchange rates and that the addition of money (and monetary prices) is but a final complication meant only to give the final realist touch to an otherwise complete and unproblematic 
Cristian Păun, Vladimir Topan, Costea Munteanu, Radu Nechita

description of complex economic reality (Salerno, 2016). To make a long story short, from a proper monetary institutional arrangement, proper money prices arise; from an improper one, distorted prices arise. And, as in all other fields or areas of the economy, the spectrum of possibilities ranges here too between two poles: the free market one, namely a private money policy at one end (with completely private selection of the monetary commodity, private production thereof, together with free coinage and free issuing of $100 \%$ covered banknotes and demand deposits - thus $100 \%$ reserves free-banking) (Herbener, 2012); and the socialist one, namely a state money policy at the other (state monopoly of money production, operated through a state central bank and a strictly regulated banking sector, usually and most probably with factional reserve banking).All the more is the above relevant for the rate of interest, both in general, and in particular in the banking sector. Monetary policy can be expected to have a direct and very significant impact on interest rates. According to PTPTI, the sole possible source of credit in society is the amount of genuine savings in existence. By means of the monetary institutional arrangement and monetary policy, this fundamental aspect is falsified in at least two ways which will have a direct impact both on the absolute level of interest rates, and in the interest gap which is the focus of the present paper. Firstly, by means of the fact that in the present economic context, fiat money is the rule of the monetary systems worldwide, the actual production of money is more or less costless as new units of money could be produced ad libitum by the mere stroke of a computer key by central bankers and their committees. Thus, for those directly connected with this monopoly source of money - namely the banking sector (the other important relation being with governments) - the actual source of funds to give further credits is much relaxed as compared to the situation where they would be obliged to discover and tap (with the associated efforts and costs) into the saving of society at large. Doubled by an inclination of central monetary authorities to favour low interest rates, the bid interest in the banking sector must as a consequence be lower than otherwise. Who would chase deponents if the central banks provides funds at low costs? Secondly, the problem is also complicated by the problem of fractional reserves which have become the normal mode of functioning for banks in the modern world (though it must be reckoned that this is by no means an unavoidable fatality). The banks make no sharp distinction between funds deposited with them for safety purposes and payments and cash management (demand deposits) on the one hand, and funds left with the bank for investment purposes (term deposits). Thus, as compared to a system which did make such a distinction (the so called $100 \%$ reserves free banking), the banking-sector can legally engage in money \& credit expansion as a matter of course (with no immediate direct cost). Even if this is also a factor that leads to generally lower interest rates than otherwise, it is very likely it will increase the interest rate gap. Banks will reduce the ask interest only so as to be able to place on the credit market the newly expanded credit (at basically zero 
Interest Rate Gap Determinants: A Global Perspective

cost). Another possible factor to influence the interest rate gap could be the general scheme of governmental interventions in the economy, not only the specific ones pertaining to the monetary and financial sector. The state intervenes in the financial sector in two roles or capacities. On the one hand it tries to act like a "normal citizen" borrower on the financial market. On the other hand, much as some might insist, the state cannot be fully separated form its own privileges connected with monetary and financial policy (after all, the prominent position of central banks as agents entrusted with monetary policy is only possible as such with the backing of the state). The financial instruments originating with governments acquire various special properties (sanctioned by legislation). For instance, they are privileged as collateral with central banks in the context of re-financing by banks from such a source. In this way, a financially active government will put downward pressure on the bid interest rate. Why, again, chase saver in the private open market, when you can use this instruments (government debt) to obtain funds by the special instruments of monetary policy? Thus, as also restated below, one possible hypothesis is that the state activity in general and involvement in the economy should correlate with a higher interest rate gap.

\section{Empirical analysis}

To illustrate the influence of various possible determinants on interest rate gap we propose a panel data regression applied on a relevant group of countries of the world for a relevant period of time. We selected variables as proxies for various potential explanatory factors derived from economic theory such as: the monetary expansion, the sophistication and development of financial sector and the state dimension and importance for economic system.

\subsection{Research hypothesis}

According with the theory, interest rate gap (the difference between bid interest rate paid for deposits and ask interest rate collected for granted loans) could be influenced by the following factors: the monetary expansion (mainly based on fractional reserves facility); the development and diversification / sophistication of the financial system and, finally, the role of the government (as borrower of capital) (Table 1).

Table 1: Research hypothesis and proxy variables

\begin{tabular}{|c|c|c|c|}
\hline $\begin{array}{l}\text { Research } \\
\text { hypothesis }\end{array}$ & $\begin{array}{l}\text { Proxy } \\
\text { variables }\end{array}$ & Variables description & $\begin{array}{l}\text { Expected } \\
\text { influence }\end{array}$ \\
\hline $\begin{array}{l}\text { H1: Money } \\
\text { expansion is } \\
\text { positively } \\
\text { influencing } \\
\text { the interest }\end{array}$ & $\begin{array}{l}\text { Broad money } \\
\text { growth rate } \\
\text { (\%, annual); } \\
\text { Variable } \\
\text { Eviews code: }\end{array}$ & $\begin{array}{l}\text { "Broad money is the sum of currency } \\
\text { outside banks; demand deposits other than } \\
\text { those of the central government; the time, } \\
\text { savings, and foreign currency deposits of } \\
\text { resident sectors other than the central }\end{array}$ & Positive \\
\hline
\end{tabular}


Cristian Păun, Vladimir Topan, Costea Munteanu, Radu Nechita

\begin{tabular}{|c|c|c|c|}
\hline rate gap & $\begin{array}{l}\text { H1_broadm } \\
\text { oney }\end{array}$ & $\begin{array}{l}\text { government; bank and traveler's checks; and } \\
\text { other securities such as certificates of } \\
\text { deposit and commercial paper" (World } \\
\text { Bank) }\end{array}$ & \\
\hline $\begin{array}{l}\text { H2: Financial } \\
\text { sector } \\
\text { development } \\
\text { and } \\
\text { sophistication } \\
\text { is negatively } \\
\text { influencing } \\
\text { the interest } \\
\text { rate gap }\end{array}$ & $\begin{array}{l}\text { Domestic } \\
\text { credit } \\
\text { provided by } \\
\text { financial } \\
\text { sector (\% of } \\
\text { GDP, } \\
\text { annual) } \\
\text { Variable } \\
\text { Eviews code: } \\
\text { H2_domcre } \\
\text { dit }\end{array}$ & $\begin{array}{l}\text { "Domestic credit provided by the financial } \\
\text { sector includes all credit to various sectors } \\
\text { on a gross basis, with the exception of credit } \\
\text { to the central government, which is net. The } \\
\text { financial sector includes monetary } \\
\text { authorities and deposit money banks, as well } \\
\text { as other financial corporations where data } \\
\text { are available (including corporations that do } \\
\text { not accept transferable deposits but do incur } \\
\text { such liabilities as time and savings } \\
\text { deposits)" (World Bank) }\end{array}$ & Negative \\
\hline $\begin{array}{l}\text { H3: } \\
\text { Dimension of } \\
\text { the state is } \\
\text { positively } \\
\text { influencing } \\
\text { the interest } \\
\text { rate gap }\end{array}$ & $\begin{array}{l}\text { General } \\
\text { government } \\
\text { final } \\
\text { consumption } \\
\text { expenditure } \\
\text { (\% of GDP, } \\
\text { annual) } \\
\text { Variable } \\
\text { Eviews code: } \\
\text { H3_govexp }\end{array}$ & $\begin{array}{l}\text { "General government final consumption } \\
\text { expenditure (formerly general government } \\
\text { consumption) includes all government } \\
\text { current expenditures for purchases of goods } \\
\text { and services (including compensation of } \\
\text { employees). It also includes most } \\
\text { expenditures on national defense and } \\
\text { security, but excludes government military } \\
\text { expenditures that are part of government } \\
\text { capital formation."(World Bank) }\end{array}$ & Positive \\
\hline
\end{tabular}

Note: for variable description we used the same description provided by World Bank, the source of these variables. (www.worldbank.org).

The explained variable in our paper is interest rate gap (\%, annual, Eviews code is IRGAP) calculated as difference between bid interest rate (for deposits) and ask interest rate (for loans). Normally, this gap is assimilated to the profit of the financial institutions (banks) involved in the financing of each studied economy. The data are annual basis computed and are collected from the World Bank database website.

\subsection{Data sample and descriptive statistics}

The panel of countries in this study was constructed by eliminating the countries with missing data for each variable. The final panel of countries containing all data for all variables and for whole observed period of time included only 78 countries only out of 245 countries. The elimination of the countries with missing data is justified by the option for a balanced panel that provides more reliable and robust regression outputs. The observed period of time included the entire period between 1999 and 2014 (16 years). Therefore, the total number of observations provided by 
Interest Rate Gap Determinants: A Global Perspective

the balanced panel is 1248 observations. Because our panel has many countries but few observed years is a short panel. All countries have data in all time periods, therefore, our panel is a balanced panel. The panel is a fixed one because all countries are observed for the same time.

Table 2: Balanced panel descriptive statistics

\begin{tabular}{|c|c|c|c|c|}
\hline Indicators & IRGAP & H1_BROADMONEY & H2_DOMCREDIT & H3_GOVEXP \\
\hline Mean & 8.270118 & 15.04224 & 63.33764 & 1.160307 \\
\hline Median & 6.486421 & 12.03834 & 49.65988 & 1.168582 \\
\hline Std. Dev. & 6.921182 & 15.21658 & 54.14229 & 0.153379 \\
\hline Skewness & 2.776193 & 4.171665 & 1.916555 & -0.247278 \\
\hline Kurtosis & 13.47214 & 40.52362 & 8.819743 & 3.790458 \\
\hline Jarque-Bera & 7305.72 & 76836.91 & 2525.231 & 45.2093 \\
\hline Observations & 1248 & 1248 & 1248 & 1248 \\
\hline
\end{tabular}

Source: own estimations

A brief descriptive statistics of the balanced panel including selected 78 countries and covering 16 years is provided by Table 2 .

\section{Panel Unit Root tests}

The timespan of our proposed balanced panel (16 years) is significantly lower than the cross-sections (78 countries). The potential stationary problems for our panel was tested by using four different panel unit root tests commonly used in similar studies: Levin, Lin \& Chu test (2002), Im, Pesaran\& Shin test (2003), Lean \& Smyth test (2010) and Wang PP - Fisher Chi-square test (2011).

Table 3: Panel Unit Root tests results

\begin{tabular}{|l|c|c|c|c|}
\hline $\begin{array}{l}\text { Variable / Unit } \\
\text { root tests }\end{array}$ & $\begin{array}{c}\text { Levin, Lin \& } \\
\text { Chu }\end{array}$ & $\begin{array}{c}\text { Im, Pesaran\& } \\
\text { Shin }\end{array}$ & $\begin{array}{c}\text { ADF - Fisher } \\
\text { Chi-square }\end{array}$ & $\begin{array}{c}\text { PP - Fisher Chi- } \\
\text { square }\end{array}$ \\
\hline \multirow{2}{*}{ IRGAP } & -16.0403 & -8.69594 & 337.558 & 325.977 \\
\cline { 2 - 5 } & $(0.000)$ & $(0.000)$ & $(0.000)$ & $(0.000)$ \\
\hline \multirow{2}{*}{ H1_broadmoney } & -11.4046 & -7.90147 & 308.106 & 512.795 \\
\cline { 2 - 5 } & $(0.000)$ & $(0.000)$ & $(0.000)$ & $(0.000)$ \\
\hline \multirow{2}{*}{ H2_domcredit } & -2.50803 & 1.8369 & 139.097 & 138.761 \\
\cline { 2 - 5 } & $(0.006)$ & $(0.967)$ & $(0.830)$ & $(0.836)$ \\
\hline \multirow{2}{*}{ H3_govexp } & -4.34895 & -1.79471 & 179.623 & 223.198 \\
\cline { 2 - 5 } & $(0.000)$ & $(0.036)$ & $(0.095)$ & $(0.000)$ \\
\hline
\end{tabular}

Source: own estimations

The outputs of panel unit root tests indicates that only H2_domcredit has stationary problems. In case of IRGAP, H1_broadmoney and H3_govexp the tests indicate the absence of stationary problems in data series. Due to this situation, we decided 
Cristian Păun, Vladimir Topan, Costea Munteanu, Radu Nechita

to generate and to use in our empirical test the first order difference for H2_domcredit. The new outputs for the four panel unit root tests applied to the first order difference of H2_domcredit are presented in Table 4.

Table 4: Panel Unit Root tests results for $\mathbf{H 2}$ domcredit first order difference

\begin{tabular}{|l|c|c|c|c|}
\hline $\begin{array}{l}\text { Variable / Unit } \\
\text { root tests }\end{array}$ & $\begin{array}{c}\text { Levin, Lin } \\
\text { \& Chu }\end{array}$ & $\begin{array}{c}\text { Im, Pesaran\& } \\
\text { Shin }\end{array}$ & $\begin{array}{c}\text { ADF - Fisher } \\
\text { Chi-square }\end{array}$ & $\begin{array}{c}\text { PP - Fisher } \\
\text { Chi-square }\end{array}$ \\
\hline \multirow{2}{*}{ H2_domcredit(-1) } & -9.39475 & -7.97484 & 323.363 & 582.928 \\
\cline { 2 - 5 } & 0.000 & 0.000 & 0.000 & 0.000 \\
\hline
\end{tabular}

Source: own estimations

According with these results, all variables included in the empirical test have no stationary problems.

\subsection{Panel Cointegration tests}

To avoid potential spurious results, we need to test if the variables used in our empirical test are cointegrated or not. In this respect, we performed three recommended panel residuals-based cointegration tests: Pedroni Panel residualsbased tests (v-test, rho-test, PP-test and ADF-test; Pedroni, 1999 and Pedroni 2004), Kao residuals-based cointegration test (1999) and unrestricted cointegration rank test that is likelihood-based cointegration test (Johansen, 1991 and Johansen, 1996) that have 'no cointegration' as null hypothesis.

Table 5: Panel Cointegration tests (Pedroni\& Kao) results

\begin{tabular}{|c|c|c|}
\hline Pedroni Residual Cointegration Test & & \\
\hline Alternative hypothesis: common AR coefs. (within-dimension) & t-stat & Prob \\
\hline Panel v-Statistic & -3.4798 & 0.9997 \\
\hline Panel rho-Statistic & 3.4661 & 0.9997 \\
\hline Panel PP-Statistic & -1.8189 & 0.0345 \\
\hline Panel ADF-Statistic & 2.3911 & 0.9916 \\
\hline Alternative hypothesis: individual AR coefs. (between-dimension) & t-stat & Prob \\
\hline Group rho-Statistic & 6.5755 & 1.0000 \\
\hline Group PP-Statistic & -4.6267 & 0.0000 \\
\hline Group ADF-Statistic & -5.3753 & 0.0000 \\
\hline KAO Cointegration test & t-stat & Prob \\
\hline ADF & -4.236355 & 0.0000 \\
\hline Unrestricted Cointegration Rank Test (No. of CEs) & Fisher & Prob \\
\hline None & 2111 & 0.0000 \\
\hline At most 1 & 845.6 & 0.0000 \\
\hline At most 2 & 380.5 & 0.0000 \\
\hline At most 3 & 305 & 0.0000 \\
\hline
\end{tabular}

Source: own estimations 
Interest Rate Gap Determinants: A Global Perspective

Excepting Panel PP-test, the Pedroni cointegration tests rejected the null hypothesis of 'no cointegration' in the variables included in the model. The Kao test also rejected the null hypothesis of 'no cointegration'. The outputs are also confirmed by the third cointegration test too. So, the conclusion is that the variables included in our model have no cointegration problems.

\subsection{Results and comments}

The first step of our analysis was to test the individual effect of each explanatory variable on the interest rate gap. The estimators were determined by using pooled OLS regression framework. Firstly we tested the individual effect of each explanatory variable and finally we tested the combined effect by including only statistically relevant variables in our model. The results of individual impact of each explanatory variable (H1_broadmoney, H2-domcredit and H3_govexp) are presented in Table 6.According with the obtained results, only broad money growth rate and domestic credit provided by financial sector are statistically relevant for explaining the level of interest rate gap. The sign of coefficients are confirming the research hypothesis: a positive effect of monetary expansion (associated to broad money growth rate) on the interest rate gap (higher quantity of money means higher interest rate gap) and a negative effect of financial sophistication and development (associated to domestic credit provided by financial sector) on the interest rate gap (more financial sophistication and development means lower interest rate gap). The third variable (H3_govexp) that is associate to the state dimension partially explain the interest rate gap (11\% significance level) but is not confirming the research hypothesis $\mathrm{H} 3$ (the coefficient is indicating a negative influence instead of expected positive influence).

Table 6: Individual estimated OLS coefficients (no fixed or random effects)

\begin{tabular}{|c|c|c|c|}
\hline \multirow{2}{*}{ Proxy variable } & \multirow{2}{*}{$\begin{array}{c}\text { Estimation coefficient } \\
\text { (significance level: } t \text {-stat) }\end{array}$} & \multicolumn{2}{|c|}{ Sign of coefficient } \\
\hline & & Expected & Obtaine \\
\hline $\begin{array}{l}\text { Broad money growth (\%, } \\
\text { annual)H1_Broadmoney }\end{array}$ & $\begin{array}{c}0,091984^{*} \\
\text { t-stat: } 7,289133 \\
\text { prob: } 0.0000\end{array}$ & Positive & Positive \\
\hline $\begin{array}{l}\text { Domestic credit provided by } \\
\text { financial sector (\% of } \\
\text { GDP)H2_Domcredit }(-1)\end{array}$ & $\begin{array}{c}-0,038739 * \\
\text { t-stat: }-11,10269 \\
\text { prob: } 0.0000\end{array}$ & Negative & Negative \\
\hline $\begin{array}{l}\text { General government final } \\
\text { consumption expenditure (\% of } \\
\text { GDP) } \\
\text { H3_Govexp }\end{array}$ & $\begin{array}{c}-2,026328 * * * \\
\text { t-stat: }-1,58669 \\
\text { prob: } 0,1128\end{array}$ & Positive & Negative \\
\hline
\end{tabular}


Cristian Păun, Vladimir Topan, Costea Munteanu, Radu Nechita

\section{Combined Panel Regression results}

The second step of our analysis was to test the combined effect of variables by including only those variables that are statistically relevant for explained variable. Therefore, in this step we tested the combined effect of broad money growth rate and domestic credit provided by financial sector to GDP. The general final government expenditures to GDP was removed from de model due to its reduced significance to explain interest rate gap. This combined regression was tested for cross-section and time random and fixed effects, in order to eliminate potential factors that could biased the final results. In the Table 7 we summarized the outputs of combined panel regression containing two explanatory variables (broad money growth rate and domestic credit provided by financial sector to GDP) for explaining the interest rate gap. The coefficients of the OLS model confirmed again the research hypothesis: a positive relationship between broad money growth rate and negative relationship between domestic credits provided by financial institutions to GDP with interest rate gap. Both coefficients are statistically significant with $1 \%$ significance level. F-statistic indicates that the model is also statistically significant with $1 \%$ significance level. Adjusted Rsquared of only 0.10 indicates a moderate to low dependence of interest rate gap to both considered explanatory variables.

Table 7: Panel regression outputs (unrestricted OLS model)

\begin{tabular}{lrrrc}
\hline Variable & Coefficient & Std. Error & t-Statistic & Prob. \\
\hline \hline H1_BROADMONEY & 0,044335 & 0,012921 & 3,43113 & 0,0006 \\
H2_DOMCREDIT(-1) & $-0,035203$ & 0,003623 & $-9,716705$ & 0,0000 \\
C & 9,674361 & 0,384907 & 25,13426 & 0,0000 \\
\hline \hline R-squared & 0,104498 & Mean dependent var & 8,13167 \\
Adjusted R-squared & 0,102963 & S.D. dependent var & 6,730259 \\
S.E. of regression & 6,374366 & Akaike info criterion & 6,545007 \\
Sum squared resid & 47418,18 & Schwarz criterion & 6,557994 \\
Log likelihood & $-3825,829$ & Hannan-Quinn criter. & 6,549905 \\
F-statistic & 68,0896 & Durbin-Watson stat & 0,144567 \\
Prob(F-statistic) & 0,00000 & & \\
\hline \hline
\end{tabular}

Source: own estimations $(*-5 \%$ significance level, $* *-10 \%$ significance level, $* * *-15 \%$ significance level)

The next step was to test the model for possible fixed effects. There are several methods to test the model for a possible impact or bias due to individual characteristics of countries included in the model: using a least square dummy variable model (LSDV model) or using F-statistic of redundant fixed effects tests. 
Interest Rate Gap Determinants: A Global Perspective

Table 8: Redundant Fixed Effects test results

\begin{tabular}{lrrr}
\hline Effects Test & Statistic & d.f. & Prob. \\
\hline Cross-section F & 36.078196 & $(77,1076)$ & 0.0000 \\
Cross-section Chi-square & 1492.763889 & 77 & 0.0000 \\
Period F & 5.480856 & $(14,1076)$ & 0.0000 \\
Period Chi-square & 80.594637 & 14 & 0.0000 \\
Cross-Section/Period F & 31.254478 & $(91,1076)$ & 0.0000 \\
Cross-Section/Period Chi-square & 1512.671211 & 91 & 0.0000 \\
\hline \hline
\end{tabular}

Source: own estimations based on panel data

The two statistic values (36.078 for cross-section $\mathrm{F}$ and 1492,763 for cross section Chi-square) and the associated p-values strongly reject the null that the cross-section effects are redundant. The same results are obtained in case of period F (5.480) and period Chi-square (80.594) and combined cross-section and period fixed effects ( $F$ statistic is 31.254 and Chi-square is 1512.671). So, we can introduce cross-section, period, cross-section and period fixed effects in our OLS. See Appendix 1for estimates generated by fixed effects OLS models (crosssection, period and both). The results presented in this appendix also confirmed that cross-section fixed effects are more powerful that period fixed effects or combined fixed effects (both cross-section and period together). F-statistic of unrestricted OLS is better than in all three cases of OLS with fixed effects.

Table 9: Random effects Breusch-Pagan Lagrange Multiplier tests

\begin{tabular}{lccc}
\hline \hline $\begin{array}{l}\text { Null (no rand. effect) } \\
\text { Alternative }\end{array}$ & $\begin{array}{c}\text { Cross-section } \\
\text { One-sided }\end{array}$ & $\begin{array}{c}\text { Period } \\
\text { One-sided }\end{array}$ & Both \\
\hline \hline Honda & 61.71664 & 0.862238 & 44.24995 \\
& $(0.0000)$ & $(0.1943)$ & $(0.0000)$ \\
King-Wu & 61.71664 & 0.862238 & 25.00040 \\
& $(0.0000)$ & $(0.1943)$ & $(0.0000)$ \\
SLM & 62.15237 & 1.128522 & -- \\
& $(0.0000)$ & $(0.1295)$ & -- \\
GHM & -- & -- & 3809.687 \\
& -- & -- & $(0.0000)$ \\
\hline
\end{tabular}

Source: own estimations based on panel data

The next step was to test the panel for random effects. In this case we assume that there is a random variation across countries that is uncorrelated with explanatory variables. In case of random effects, the individual characteristics of countries (time-invariant) included in the panel data are relevant for explain the interest rate 
Cristian Păun, Vladimir Topan, Costea Munteanu, Radu Nechita

gap. The test we used are included in the family of Lagrange multiplier tests: uniformly most powerful LM test also known as Honda test (1985), locally mean most powerful test also known as King-Wu test (1997), standardized LM test or SLM test (Baltagi et al., 1999) and GHM test (Gourieroux, Holly, and Monfort, 1982).

Table 10: Hausman Test results on correlated random effects applied to restricted panel regression

\begin{tabular}{|c|c|c|c|}
\hline Test Summary & $\begin{array}{l}\text { Chi-Sq. } \\
\text { Statistic }\end{array}$ & $\begin{array}{l}\text { Chi-Sq. } \\
\text { d.f. }\end{array}$ & Prob. \\
\hline Cross-section random & 2.422105 & 2 & 0.2979 \\
\hline
\end{tabular}

Cross-section random effects test comparisons:

\begin{tabular}{ccrcc} 
Variable & \multicolumn{1}{c}{ Fixed } & Random & Var(Diff.) & Prob. \\
\hline \hline H1_BROADMONEY & 0.032120 & 0.031959 & 0.000001 & 0.8791 \\
H2_DOMCREDIT(-1) & -0.018480 & -0.022917 & 0.000010 & 0.1642 \\
\hline \hline
\end{tabular}

Source: own estimations

The results of these tests strongly reject the null that cross section (onesided), period (one-sided) random effects are redundant. Random effects (crosssection, period and both) could be introduced in our OLS model. See Appendix 2 for estimators returned by random effects OLS models. According with presented results, we can observe that model with period random effects provided the most relevant estimates (highest F-statistic). By comparing the two estimating methods proposed for this panel data analysis (fixed effects and random effects), we can observe slightly differences in the values of estimators. Consequently, we performed the Hausman test that confirm which is the best recommended estimating method for this panel data analysis. The Hausman test is proposed to establish what panel data estimating method (fixed vs random effects) is more consistent. The results summarized in the Table 10 indicate that we cannot reject the null on a $5 \%$ significance level, and therefore we have that the unobserved characteristics and the explanatory variables broad money growth annual rate and domestic credit provided by financial institutions are uncorrelated. The null hypothesis the random effects model are appropriate is accepted. Therefore, we can conclude that, the random effects estimating method is the most efficient to be use in this case. The period random effects OLS model seems to be the most appropriate in this case. 
Interest Rate Gap Determinants: A Global Perspective

Table 11: Comparative estimates between different Panel EGLS

\begin{tabular}{|r|c|c|c|}
\hline Variable & $\begin{array}{c}\text { Panel EGLS } \\
\text { (Period random eff.) }\end{array}$ & $\begin{array}{c}\text { Panel EGLS } \\
\text { (Period weights) }\end{array}$ & $\begin{array}{c}\text { Panel EGLS } \\
\text { (Cross-section } \\
\text { weights) }\end{array}$ \\
\hline H1_BROADMONEY & & & \\
Coefficient & 0.044 & 0.038 & 0.028 \\
t-Statistic & 3.440 & 2.906 & 5.156 \\
Prob. & 0.001 & 0.004 & 0.000 \\
\hline H2_DOMCREDIT(-1) & & & \\
Coefficient & -0.035 & -0.035 & -0.032 \\
t-Statistic & -9.741 & -9.879 & -36.188 \\
Prob. & 0.000 & 0.000 & 0.000 \\
\hline C & & & 9.121 \\
Coefficient & 9.674 & 9.646 & 73.890 \\
t-Statistic & 25.196 & 25.137 & 0.000 \\
Prob. & 0.000 & 0.000 & $\mathbf{7 2 5 . 0 9 4}$ \\
\hline F-statistic & $\mathbf{6 8 . 0 9 0}$ & $\mathbf{6 6 . 7 3 6 4}$ & 0.000 \\
Prob. (F-statistic) & 0.000 & 0.000 & 6.101 \\
S.E. of regression & 6.374 & 6.373 & \\
\hline
\end{tabular}

Source: own estimations

Finally, we tested the potential presence of heteroskedasticity in the absence of fixed effects (this hypothesis was confirmed by Hausman test). The heteroskedasticity is a common problem of panel data. We tested for both types of heteroskedasticity: period and cross-section heteroskedasticity (only on unrestricted OLS, fixed effects being rejected by Hausman test). The results are summarized in the Table 11. The best estimates are obtained by introducing crosssection heteroskedasticity. The final coefficients are robust and statistically significant (1\% significance level) and confirmed again the research hypothesis: a positive influence of monetary expansion and a negative influence of financial sector development and sophistication on interest rate gap.

\section{Concluding remarks}

Our paper is focused on the study of capital and interest rate related problems, by looking to a very specific problem of interest rate gap determinants such as monetary expansion, financial sector sophistication and development or public sector dimension. The paper explains the nature and the role of capital for economic development, the importance of interest rate for capital allocation by financial institutions through specific markets. The paper includes an empirical study developed on a balanced panel of 78 countries of the world that illustrate the role of monetary policy (money and credit expansion) and the role played by financial institutions for the level of interest rate gap. The results we obtained are 
Cristian Păun, Vladimir Topan, Costea Munteanu, Radu Nechita

robust and statistically significant confirming the research hypothesis we derived from economic theory: a positive and strong relationship between broad money growth rate (proxy of monetary expansion) and interest rate gap and a negative and strong relationship between domestic credit provided by financial institutions to GDP (proxy for financial sector development and sophistication) and interest rate gap. The empirical test found a weak and not significant relationship between public sector dimension (proxied by general final government expenditures to GDP) and interest rate gap. Further developments of our research will be to extend the study to a larger number of countries by trying to test the research hypothesis on an unbalanced panel data, to improve the proxy variables by including more relevant indicators (combining them by using principal components analysis framework) and to search for more potential determinants for interest rate gap derived from economic theory.

\section{REFERENCES}

[1] Böhm-Bawerk, Eugen von (1959),Capital and Interest (3 vols.), Libertarian Press, South Holland, Illinois;

[2] Clark, John Bates (1908), The Distribution of Wealth: A Theory of Wages, Interest and Profits; New York, The Macmillan Company;

[3] De Soto, Jesús Huerta (2006), Money, Bank Credit, and Economic Cycles. The Ludwig von Mises Institute, Auburn, Alabama, USA;

[4] Fetter, Frank A. (1977), Capital, Interest, and Rent. Essays in the Theory of Distribution; Institute for Humane Studies, Menlo Park, California, 1977;

[5] Fisher, Irving (1930), The Theory of Interest; Macmillan Co., New York;

[6] Garrison, Roger W. (2001),Timean Money. The Macroeconomics of Capital Structure; Routledge, London and New York;

[7] Hayek, Friedrich A. (Ed.), (1935),Collectivist Economic Planning. Critical Studies on the Possibilities of Socialism by N.G. Pierson, Ludwig von Mises, Georg Halm, and Enrico Barone; Routledge\& Kegan Paul Ltd., London;

[8] Hayek, Friedrich A. (2008), Prices and Production and Other Works: F.A. Hayek on Money, the Business Cycle, and the Gold Standard; L. v. Mises Institute, Auburn, Alabama, USA;

[9] Hazlitt, Henry (2007), The Failure of "New Economics". An Analysis of the Keynesian Fallacies; L.v. Mises Institute, Auburn, Alabama, USA;

[10] Herbener, Jeffrey M. (2012),Leave Money Production to the Market; Written Testimony before the Subcommittee on Domestic Monetary Policy and Technology Committee on Financial Services, US House of Representatives, May 8, 2012, available at https://mises.org/library/leavemoney-production-market; 
Interest Rate Gap Determinants: A Global Perspective

[11] Herbener, Jeffrey M. (Ed.) (2011),The Pure Time-Preference Theory of Interest; The Ludwig von Mises Institute, Auburn, Alabama, USA;

[12] Hülsmann, Jörg Guido (2002), A Theory of Interest; Quarterly Journal of Austrian Economics, Vol. 5, no. 4 (Winter), pp. 77-110;

[13] Keynes, John Maynard (2007),The General Theory of Employment, Interest and Money; Palgrave Macmillan (for the Royal Economic Society);

[14] Kirzner, Israel M. (1996), Essays on Capital and Interest: An Austrian Perspective; Edward Elgar;

[15] Knight, Frank H. (1934), Capital, Time, and the Interest Rate; Economica, New Series 1, August, pp. 257-286;

[16] Knight, Frank H. (1933), Capitalistic Production, Time and the Rate of Return, in "Economic Essays in Honour of Gustav Cassel", George Allen \& Unwin, London, pp. 327-342;

[17] Menger, Carl (2011),Principles of Economics; The Ludwig von Mises Institute, Auburn, Alabama, SUA;

[18] Mera, Xavier (2010), The Sad State of Financial Economics Teaching, available at https://mises.org/library/sad-state-financial-economics-teaching;

[19] Mises, Ludwig von (2012),Economic Calculation in the Socialist Commonwealth; The Ludwig von Mises Institute, Auburn, Alabama, USA;

[20] Mises, Ludwig von (2008),Human Action. A Treatise on Economics; The Ludwig von Mises Institute, Auburn, Alabama, USA;

[21] Mishkin, Frederis S. (2004), The Economics of Money, Banking and Financial Markets; Pearson \& Addison Wesley;

[22] Pătruți, Alexandru (2016),Teoria structurii de producție (The Theory of the Structure of Production); Editura Universității“A.I. Cuza”, Iași;

[23] Păun, Cristian; Topan, Mihai-Vladimir (2013),The Monetary Causes of Inflation in Romania; Romanian Journal of Economic Forecasting, Volume 16, Issue 1, pp. 5-23;

[24] Rothbard, Murray N. (2009),Man, Economy, and State with Power and Market; The Ludwig Mises Institute, Auburn, Alabama, USA;

[25] Salerno, Joseph T. (2016), The Development of the Neutral Money Concept: The Austrian School Further Dehomogenized, working paper available at http://papers.ssrn.com/sol3/papers.cfm?abstract_id=2738140;

[26] Strigl, Richard von (2000),Capital and Production; The Ludwig von Mises Institute, Auburn, Alabama, SUA;

[27] Topan, Mihai-Vladimir; Păun, Cristian (2013),A Note on Two Erroneous Ways of Defending the Pure Time Preference Theory of Interest; Quarterly Journal of Austrian Economics, vol. 16, no. 3, pp. 299-316;

[28] Wicksell, Knut (1962),Interest and Prices. A Study of the Causes Regulating the Value of Money; Sentry Press, New York, USA. 
Cristian Păun, Vladimir Topan, Costea Munteanu, Radu Nechita

Appendix 1: Estimators determined by Panel OLS model with fixed effects

\begin{tabular}{|r|c|c|c|}
\hline Variable & Cross-section FE & Period FE & Both FE \\
\hline H1_BROADMONEY & & & \\
Coefficient & 0.032 & 0.043 & 0.029 \\
t-Statistic & 3.728 & 3.255 & 3.353 \\
Prob. & 0.000 & 0.001 & 0.001 \\
\hline H2_DOMCREDIT(-1) & & & \\
Coefficient & -0.018 & -0.035 & -0.009 \\
t-Statistic & -2.769 & -9.570 & -1.327 \\
Prob. & 0.006 & 0.000 & 0.185 \\
Coefficient & 8.810 & & \\
t-Statistic & 18.563 & 9.658 & 8.255 \\
Prob. & 0.000 & 24.975 & 17.574 \\
& 38.600 & 0.000 & 0.000 \\
\hline F-statistic & 0.000 & 9.790 & 35.501 \\
Prob. (F-statistic) & 3.577 & 0.000 & 0.000 \\
S.E. of regression & & 6.359 & 3.478 \\
\hline
\end{tabular}

Source: own estimation based on balanced panel data

Appendix 2: Estimators determined by Panel OLS model with random effects

\begin{tabular}{|r|c|c|c|}
\hline Variable & Cross-section RE & Period RE & Both RE \\
\hline H1_BROADMONEY & & & \\
Coefficient & 0.032 & 0.044 & 0.030 \\
t-Statistic & 3.737 & 3.440 & 3.518 \\
Prob. & 0.000 & 0.001 & 0.001 \\
\hline H2_DOMCREDIT(-1) & & & \\
Coefficient & -0.023 & -0.035 & -0.018 \\
t-Statistic & -3.910 & -9.741 & -3.087 \\
Prob. & 0.000 & 0.000 & 0.002 \\
\hline C & & & \\
Coefficient & 9.090 & 9.674 & 8.815 \\
t-Statistic & 12.262 & 25.196 & 11.650 \\
Prob. & 0.000 & 0.000 & 0.000 \\
\hline F-statistic & 18.572 & 68.090 & 13.442 \\
Prob. (F-statistic) & 0.000 & 0.000 & 0.000 \\
S.E. of regression & 3.577 & 6.374 & 3.498 \\
\hline
\end{tabular}

Source: own estimation based on balanced panel data 